\title{
HAK KONSTITUSIONAL PENGUSULAN PASANGAN CALON PRESIDEN DAN WAKIL PRESIDEN DALAM SISTEM PEMILIHAN UMUM DI INDONESIA
}

\author{
Irwansyah \\ Dosen Hukum Tata Negara Fakulatas Syariah dan Hukum \\ Universitas Islam Negeri Sumatera Utara
}

\begin{abstract}
Abstrak
Political parties in the constitution of the Republic of Indonesia and the law have constitutional rights to propose candidates for President and Deputy President. The current electoral system requires that before nominating the President and Vice President, political parties must have 20 percent of the vote in the legislature / DPR or obtain 25 percent of the national legitimate votes in the previous general election. With the implementation of this system, not all political parties can propose candidates for President and Vice President candidates. Then what is the fate of the party that does not achieve this provision even the new party which is also the first time participating in the general election. With the application of the nomination threshold in the electoral system in Indonesia, it will certainly restrict or limit the constitutional rights of political parties that do not meet the desired conditions of the threshold.
\end{abstract}

Keywords: Constitutional rights, political parties, president and vice president.

Partai politik dalam konstitusi Republik Indonesia maupun undang-undang memiliki hak konstitusional untuk mengusulkan pasangan calon Presiden dan Wakil Presiden. Sistem pemilu saat ini menghendaki bahwa sebelum mencalonkan Presiden dan Wakil Presiden, partai politik harus memiliki 20 persen suara di legilatif/DPR atau memperoleh 25 persen suara sah nasional pada pemilihan umum sebelumnya. Tetunya dengan keberlakuan sistem ini, tidak semua partai politik dapat mengusulkan pasangan calon Presiden dan Wakil Presiden. Lantas bagaimana nasib partai yang tak memcapai ketentuan tersebut bahkan partai baru yang juga baru pertama kali ikut dalam pemilihan umum. Dengan keberlakuan ambang batas pencalonan dalam sistem pemilihan umum di Indonesia, tentunya akan merestriksi ataupun membatasi hak-hak konstitusional partai politik yang tak mencukupi ketetentuan yang dikehendaki ambang batas tersebut.

Kata kunci: Hak Konstitusional, Partai politik, Presiden dan Wakil Presiden

\section{Pendahuluan}

Dalam kehidupan berbangsa dan bernegara dewasa ini, konstitusi tidak hanya sebagai norma tertinggi, melainkan pula dipandang juga sebagai landasan suatu negara. Hal inilah yang yang perlu segera kita pahami agar sebagai bangsa yang telah mempunyai konstitusi, harus pula mengenal konstitusi secara utuh. ${ }^{1}$ Dalam negara modern, penyelenggaraan kekuasaan negara dilakukan

${ }^{1}$ Andryan. 2017. Dinamika Ketatanegaraan Rezim Reformasi. Medan: Pustaka Prima, hal. 37. berdasarkan hukum dasar (droit constitusionil). ${ }^{2}$ Konstitusi menjadi peraturan dasar dan memuat ketentuan-ketentuan pokok, serta menjadi suatu sumber dalam perundang-undangan yang berlaku.

Pada dasarnya, konstitusi adalah suatu dokumen penting yang mengandung peraturan-peraturan dasar mengenai struktur pemerintahan, hak dan kewajiban serta pembatasan dari kewenangan negara. karena konstitusi merupakan hukum dasar (groundnorm), maka secara lebih luas biasa

2 H. Dahlan Thaib, Jazim Hamidi, Hj. Ni'matul Huda. 2015. Teori Dan Hukum Konstitusi. Jakarta: Rajawali Pers, hal. 58. 
berwujud teks tertulis (written texts) dan tidak tertulis (unwritten texts), hal tersebut tergantung pada sistem hukum yang dianut antara Civil Law atau Common Law.

Amandemen ketiga Undang-Undang Dasar Negara Republik Indonesia Tahun 1945 atau yang disingkat dengan UUD NRI Tahun 1945, dalam Pasal 3 UUD NRI Tahun 1945 dikatakan bahwa negara Indonesia adalah negara hukum. Maka dari itu seleruh kebijakan ataupun penyelenggraan negara Indonesia harus didasarkan atas suatu peraturan atau hukum.

Demokrasi berkaitan erat dengan prinsip penyelenggaraan negara hukum dengan alasan bahwa dalam literasi demokrasi, pemilihan umum merupakan salah satu dari Sembilan prinsip negara hukum. Pemilihan umum rakyat merupakan bagian dari pelaksanaan prinsip demokrasi, dimana rakyat dapat memilih pemimpin negara atau wakilwakilnya yang berhak membuat suatu kebijakan berdasarkan kehendak rakyat yang digariskan oleh pemimpin negara atau wakil-wakil rakyat tersebut. ${ }^{3}$ Pemilihan umum (pemilu) merupakan instrumen penting dalam negara demokrasi yang menganut sistem perwakilan. ${ }^{4}$

Ikut serta di dalam pemilu merupakan salah satu bentuk partisipasi politik minimal warga negara. Melalui pemilu warga negara memilih para wakil yang akan duduk di lembaga-lembaga-lembaga perwakilan. ${ }^{5}$ Hakikat pemilihan umum adalah sebagai sarana demokrasi yang intinya untuk menyelenggarakan suatu pemerintahan negara oleh, dari, dan untuk rakyat. Atau dengan kata lain mewujudkan kedaulatan yang berada ditangan rakyat dalam bingkai negara hukum yang bersifat demokratis. Oleh karena itu, agar derap demokrasi dapat berputar sesuai sumbu konstitusi, maka demokrasi itu harus dijaga. Pelaksanaan demokrasi

3 Ahmad Farhan Subhi. "Pengusulan Pasangan Calon Presiden Dan Wakil Presiden Sebagai Peserta Pemilu Menurut Undang-Undang Pilpres". Jurnal Cita Hukum. Vol. 11 No. 2. Pada Desember 2015, hal. 338.

4 Moh. Mahfud MD. 2014. Politik Hukum Indonesia. Jakarta: Rajawali Pers, hal. 60.

${ }^{5}$ Kacung Marijan. 2012. Sistem Politik Indonesia. Jakarta: Kharisma Putra Utama, hal. 125. konstitusi terlihat dalam kegiatan pemilihan umum, pembentukan aturan dan pelaksanaan kewenangan lembaga negara. ${ }^{6}$

Pemilu sebagai sebuah mekanisme politik dalam mencerminkan kedaulatan rakyat sebagaimana yang tertuang dalam amanat konstitusi Republik Indonesia.Pasca amandemen UUD NRI Tahun 1945, pemilihan Presiden dan Wakil Presiden tidak lagi dilakukan oleh Majelis Permusyawaratan Rakyat (MPR), tetapi dipilih secara langsung oleh rakyat.

Untuk menyelenggarakan pemilihan umum secara demokratis, dibentuklah sebuah aturan atau undang-undang yang mencakup segala hal mengenai persyaratan maupun teknis pelaksanaan pemilihan umum. Dalam pemilihan umum presiden dan wakil presiden, dibentuk Undang-Undang Nomor 23 Tahun 2003 yang kemudian dirubah dengan Undang-Undang Nomor 42 Tahun 2008 Tentang Pemilihan Umum Presiden dan Wakil Presiden, kemudian saat ini peraturan tersebut digabungkan dengan undang-undang pemilihan umum legislatif menjadi Undang-Undang Nomor 7 Tahun 2017 Tentang Pemilihan Umum.

Terdapat ketentuan di dalam Pasal 221 UndangUndang Pemilu yang akan memberikan pemahaman bahwa satu-satunya mekanisme atau jalur untuk menjadi calon Presiden dan Wakil Presiden adalah melalui usulan partai politik atau gabungan partai politik peserta pemilu. Dengan kata lain, hak untuk mengajukan pasangan calon Presiden dan Wakil Presiden adalah hak eksklusif partai politik peserta pemilu dan tidak diperkenankan atau tidak ada kemungkinan sama sekali bagi pasangan calon Presiden dan Wakil Presiden perseorangan atau independen di luar dari yang diusulkan oleh organisasi non-partai politik.

Partai politik memiliki hak konstitusional atau hak-hak yang diatur dalam UUD NRI Tahun $1945 .{ }^{7}$ Hak tersebut adalah hak untuk mengusulkan calon Presiden dan Wakil Presiden, seperti yang tertuang dalam Pasal 6A ayat (2). Berdasarkan pasal

\footnotetext{
${ }^{6}$ Ahmad Farhan Subhi. "Pengusulan Pasangan.338

${ }^{7}$ Lihat Penjelasan Pasal 51 ayat (1) Undang-Undang Nomor 24 Tahun 2003 Tentang Mahkamah Konstitusi.
} 
tersebut, partai politik atau gabungan partai politik peserta pemilihan umum dapat mengusulkan calon Presiden dan Wakil Presiden dalam pemilu Presiden dan Wakil Presiden.

Pasal 12 huruf i Undang-Undang Nomor 2 Tahun 2011 Tentang Partai Politik juga menjelaskan bahwa partai politik berhak mengusulkan pasangan calon Presiden dan Wakil Presiden, calon gubernur dan wakil gubernur, calon bupati dan wakil bupati, serta calon walikota dan wakil walikota sesuai dengan peraturan perundangundangan. ${ }^{8}$ Berdasarkan peraturan yang telah disebutkan, baik dalam konstitusi maupun undangundang, hak untuk mengsulkan pasangan calon presiden dan wakil presiden adalah mutlak hak konstitusional dari partai politik.

Kemudian ketentuan tersebut dapat dipahami pula dalam Pasal 222 Undang-Undang Pemilu di atas, bahwa pasangan calon Presiden dan Wakil Presiden diusulkan oleh partai politik atau gabungan partai politik peserta pemilihan umum yang memenuhi persyaratan perolehan kursi paling sedikit 20 persen dari jumlah kursi DPR atau memperoleh 25 persen dari suara sah nasional pada pemilu anggota DPR sebelumnya. Ini berarti menetapkan suatu ambang batas perolehan suara dalam pemilu legislatif agar suatu partai politik atau gabungan partai politik dapat mengusulkan pasangan calon Presiden dan Wakil Presiden atau presidential threshold.

Merujuk kepada UUD NRI Tahun 1945, Pasal 6A ayat (2) menyebutkan "Pasangan calon Presiden dan Wakil Presiden diusulkan oleh partai politik atau gabungan partai politik peserta pemilihan umum sebelum pelaksanaan pemilihan umum". Berdasarkan ketetentuan tersebut, semua partai politik yang telah disetujui oleh Komisi Pemilihan Umum sebagai partai politik peserta pemilu dapat mengusulkan calon Presiden dan Wakil Presiden.

Pasal 28C ayat (2) yang menyebutkan, "setiap orang berhak memajukan dirinya dalam memperjuangkan haknya secara kolektif untuk

${ }^{8}$ Lihat: Pasal 12 huruf I Undang-undang No. 2 Tahun 2011 Tentang Partai Politik. membangun masyarakat, bangsa, dan negaranya". Apabila ambang batas pencalonan presiden dan wakil presiden (presidential threashold) diterapkan dalam pemilihan umum Presiden dan Wakil Presiden, maka akan mereduksi hak-hak warga negara yang memiliki integritas ataupun kemampuan dalam memimpin untuk membangun ataupun memajukan bangsa dan negara kita.

Berkaca juga pada Pasal 28D ayat (3) UUD NRI Tahun 1945 yang menyebutkan "setiap warga negara berhak memperoleh kesempatan yang sama dalam pemerintahan". Dengan diberlakukannya ambang batas pencalonan presiden dan wakil presiden dalam pemilu Presiden dan Wakil Presiden tentunya akan menciderai hak-hak konstitusional partai politik yang akan mengusulkan calon Presiden dan Wakil Presiden yang besaran presentase suara dalam pemilu legislatif tidak mencapai ketentuan yang berlaku dalam Undang-Undang Pemilu.

Partai politik adalah wadah untuk saluran politik bagi rakyat sebagai pemegang kedaulatan tertinggi sebuah negara, maka keberadaan partai-partai tidak boleh dibatasi jumlahnya. Partai dapat bertumbuh setiap saat seiring dengan tumbuhnya dinamika masyarakat dari waktu ke waktu. Siklus politik ini harus berlangsung agar tidak terjadi kejenuhan rakyat, dimana partai-partai beserta aturan main yang ada membelenggu aspirasi rakyat sebagai pemegang kedaulatan. ${ }^{9}$

Penulis menilik dari salah satu contoh partai politik yang merasa dirugikan dengan berlakunya ambang batas pencalonan sesuai Undang-Undang Pemilu. Partai Bulan Bintang (PBB) pada pemilu 2019 akan mengusulkan ketua umum partainya yaitu Yusril Ihza Mahendra. Namun hal itu akan terganjal karena ada syarat presidential threshold sebesar 20 persen. Kendati demikian dengan adanya ambang batas ini ketua umum PBB merencanakan dilakukannya judicial review Undang-Undang Nomor 7 Tahun 2017 Tentang Pemilu ke Mahkamah Konstitusi karena dianggap menghambat hak konstitusional partai politik

9 Lihat putusan Mahkamah Konstitusi Nomor 51-5259/PUU-VI/2008, hal. 7. 
dalam mengusulkan calon Presiden dan Wakil Presiden. ${ }^{10}$

Partai Islam Damai Aman atau partai Idaman juga merasa dirugikan dengan keberlakuaan sistem ambang batas pencalonan untuk partai politik dalam mengusulkan pasangan calon Presiden dan Wakil Presiden. Partai Idaman sendiri merupakan partai politik baru yang akan ikut dalam pesta demokrasi pemilihan umum. Dalam hal ini, Partai Idaman melalui Ketua Umumnya Rhoma Irama dan Sekjen Partai Idaman melakukan judicial review terkait norma ambang batas pencalonan tersebut ke Mahkamah Konstitusi. Dan pada putusannya nomor 53/PUU-XV/2017, Mahkamah Konstitusi tetap memutuskan bahwa ambang batas pencalonan presiden dan wakil presiden adalah konstitusional atatu tidak bertentangan dengan UUD NRI Tahun 1945. Sehingga Partai Idaman sendiri tak dapat mencalonkan Presiden dan Wakil Presiden karena tak memenuhi syarat yang dimaksudkan dalam ambang batas tersebut.

\section{Kedudukan Partai Politik Dalam Mengusulan Pasangan Calon Presiden Dan Wakil Presiden}

Politik adalah usaha menggapai kehidupan yang baik. Kekuasaan adalah kemampuan seseorang atau suatu kelompok untuk mempengaruhi perilaku seseorang atau kelompok lain, sesuai dengan keinginan pelaku. ${ }^{11}$ Atau dengan kata lain kekuasaan merupakan suatu kemampuan seseorang atau kelompok manusia untuk mempengaruhi tingkah laku seseorang atau kelompok orang lain sedemikian rupa sehingga tingkah laku seseorang/kelompok orang tersebut menjadi sesuai dengan keinginan dan tujuan dari orang yang memiliki kemampuan itu.

Kekuasaan politik adalah untuk mempengaruhi kebijakan umum baik dalam proses terbentuknya maupun akibat-akibatnya sesuai dengan tujuantujuan pemegang kekuasaan itu sendiri. Kekuasaan dalam negara selalu berbentuk piramida, ini selalu

${ }^{10}$ Bisma Alief Laksana, "Diusung PBB Jadi Capres, Yusril Segera Gugat Presidential Threshold", melalui www.detiknews.com, diakses Senin, 23 Oktober 2017, Pukul 15.00 wib.

${ }^{11}$ Bisma Alief Laksana, "Diusung, hal. 17. mengsubbordinasi kekuasaan-kekuasaan lain. Ciriciri kekuasaan negara:

1. Adanya unsur kekuatan memaksa.

2. Negara memiliki monopoli kekuasaan dalam menentukan tujuan bersama.

3. Sifat kekuasaan negara mencakup semua orang tanpa terkecuali. ${ }^{12}$

Sarjana yang melihat kekuasaan inti dari politik beranggapan bahwa politik adalah semua kegiatan yang menyangkut masalah memperebutkan dan mempertahankan kekuasaan. Biasanya dianggap bahwa perjuangan kekuasaan (power struggle) ini mempunyai tujuan yang menyangkut kepentingan seluruh masyarakat. ${ }^{13}$

Kekuasaan tertinggi negara ataupun kedaulatan adalah berada ditangan rakyat, ini sesuai dengan cerminan Pasal 1 ayat (2) UUD NRI Tahun 1945. Dimana demokrasi merupakan senajata utamanya, dari rakyat, oleh rakyat dan untuk rakyat.

Demokrasi menurut J Rousseau dalam bukunya "Du contract Social" adalah suatu demokrasi langsung dimana pemerintahan diselenggarakan berdasarkan kehendak umum atau sebagian besar dari warga negara. Ajaran ini sulit diterapkan karena luasnya wilayah, banyaknya penduduk, dan kepentingan yang beragam sehingga jalan keluarnya adalah melalui sistem perwakilan. ${ }^{14}$

Pengertian pemerintahan dengan sistem perwakilan menurut konfrensi Internasional Comision of Jurist di Bangkok 1965, pemerintahan perwakilan adalah pemerintahan yang memperoleh kekuasaan dan kewenangan dari rakyat, dimana kewenangan dan kekuasaan itu diperoleh melalui perwakilan yang dipilih secara bebas dan bertanggung jawab kepada pemilihnya. Syaratsyaratnya: ${ }^{15}$

1. Proteksi konstitusional.

12 Edy Kurniawan, "Partai politik Dan Pemilu", melalui www.belajarhukumonline.com, diakses Jum'at, 5 Januari 2017, Pukul 15.00 wib.

${ }^{13}$ Edy Kurniawan, "Partai politik, 18.

${ }^{14}$ Edy Kurniawan, "Partai politik, 18.

${ }^{15}$ Edy Kurniawan, "Partai politik, 18. 
2. Pengadilan-pengadilan yang bebas dan tidak memihak.

3. Pemilihan-pemilihan yang bebas.

4. Kebebasan menyatakan pendapat.

5. Kebebasan berserikat dan tugas oposisi.

6. Harus ada pendidikan civics.

Konsekuensi dari Representative Government adalah: ${ }^{16}$

1. Keharusan adanya lembaga perwakilan.

2. Keharusan adanya seleksi, baik pemilu yang bebas dan rahasia, maupun dengan cara lain.

3. Keharusan adanya partai politik.

4. Keharusan adanya lembaga yang mempunyai tugas pelaksanaan dan bertanggungjawab kepada rakyat melalui badan perwakilan rakyat.

Hampir tak ada sistem pemerintahan yang bersedia menerima cap tidak demokratis, maka hampir tak ada sistem pemerintahan yang tidak menjalankan pemilu. Pemilu pada hakikatnya merupakan sistem penjaringan pejabat publik yang banyak digunakan oleh negara-negara di dunia dengan sistem pemerintahan demokrasi. ${ }^{17}$

Bagi sejumlah negara yang menerapkan atau mengklaim diri sebagai negara demokrasi (berkedaulatan rakyat), pemilu memang dianggap sebagai lambang sekaligus tolak ukur utama dan pertama dari demokrasi. Artinya, pelaksanaan dan hasil pemilu merupakan refleksi dari suasana keterbukaan dan aplikasi dari nilai-nilai dasar demokrasi, di samping perlu adanya kebebasan berpendapat dan berserikat yang dianggap cerminan pendapat warga negara. Alasannya, pemilu memang dianggap akan melahirkan suatu representatif aspirasi rakyat yang tentu saja berhubungan erat dengan legitimasi bagi pemerintah. Melalui pemilu, demokrasi sebagai sistem yang menjamin kebebasan warga negara terwujud melalui penyerapan suara sebagai bentuk partisipasi publik secara luas. Dengan kata lain bahwa pemilu merupakan simbol daripada kedaulatan rakyat. ${ }^{18}$

Kebanyakan negara demokrasi menganggap pemilihan umum sebagai lambang sekaligus tolak ukur dari demokrasi di negara tersebut. Hasil pemilihan umum yang diselenggarakan dalam suasana keterbukaan dengan kebebasan berpendapat dan kebebasan berserikat. Sekalipun demikian pemilihan umum tidak merupakan satusatunya tolak ukur dan perlu dilengkapi dengan pengukuran beberapa kegiatan lain yang lebih bersifat berkesinambungan, seperti partisipasi dalam kegiatan partai, lobbying, dan sebagainya.

Baik dalam pemerintahan suatu negara yang konservatif ataupun yang revolusioner, atau dalam suatu pemerintahan yang didukung oleh kelompok elite tertentu ataupun yang didukung oleh massa, atau suatu pemerintahan yang mengikuti sistem pluralis demokrasi atau dictator monolitis, maka suatu partai politik dibentuk tidak ada lain kecuali untuk berfungsi menjalankan kekuasaan politik. Fungsi ini dilakukan oleh partai politik baik melalui ketika membentuk pemerintahan atau ketika partai politik berfungsi sebagai oposisi di dalam pemerintahan. Fungsi-fungsi ini merupakan suatu fungsi yang amat penting dalam ikut menentukan kebijakan nasional. ${ }^{19}$

Partai politik pada dasarnya merupakan suatu kelompok yang terorganisir, dimana anggotanya memiliki orientasi, nilai-nilai dan cita-cita yang sama dengan tujuan memperoleh kekuasaan politik dengan merebut jabatan-jabatan politik secara konstitusional melalui pemilihan umum.

Soltau juga menjelaskan bahwa partai politik sebagai kelompok warga negara yang sedikit banyak terorganisasikan, yang bertindak sebagai suatu kesatuan politik dan dengan memanfaatkan kekuasaannya untuk memilih, bertujuan untuk menguasai pemerintahan dan menjalankan kebijakan umum yang mereka buat. ${ }^{20}$ Persoalan

\footnotetext{
18 Ibid.

${ }^{19}$ Miftah Thoha, Op. Cit., hal. 99.

20 Artis."Eksistensi Partai Politik dan Pemilu Langsung Dalam Konteks Demokrasi Indonesia.Jurnal
} 
yang dihadapi dalam sistem kepartaian di Indonesia adalah belum berjalannya secara maksimal funsi yang dimiliki oleh partai politik, baik fungsi partai politik terhadap negara maupun fungsi partai politik terhadap rakyat.

Menurut Miriam Budiardjo fungsi partai politik ada empat, yaitu: ${ }^{21}$

1. Sarana komunikasi politik.

2. Sosialisasi politik (political sosciallization).

3. Sarana rekrutmen politik (political recruitment).

4. Pengatur konflik (conflict management).

Selanjutnya menurut Yves Meny and Andrew Knapp fungsi partai politik itu mencakup antara lain: ${ }^{22}$

1. Mobilisasi dan integrasi.

2. Sarana pembentukan pengaruh terhadap prilaku memilih (votting patterns).

3. Sarana rekrutmen politik.

4. Sarana elaborasi pilihan-pilihan kebijakan.

Dalam konteks bernegara keberadaan partai politik dalam hubungannya dalam sistem bernegara ini memainkan berbagai peran dan fungsi yang sangat strategis sifatnya, dimana salah satunya adalah pada fungsi input yakni, partai politik tidak hanya menjadi saran pendidikan politik dan komunikasi politik serta rekriutmen politik, akan tetapi juga menjadi sarana agregasi kepentingan dan atau artikulasi kepentingan bagi masyarakat. ${ }^{23}$ Oleh karena itu keberadaan dan peran partai politik dalam politik bernegara khususnya dalam mendukung pemerintahan yang berdaulat untuk menuju kepada kesejahteraan rakyat sangatlah pentingdan menentukan. Hal itu akan terwujud dalam hubungannya dengan proses pembuatan dan penerapan kebijakan yang dibuat oleh pemerrintah.

Dalam sebuah negara yang demokratis sifatnya maka keberadaan partai politik sangatah

Sosial Budaya.Vol. 9 No. 1.Pada Januari-Juli 2012, hal. 66.

\footnotetext{
${ }^{21}$ Ibid., hal. 68 .

${ }^{22}$ Ibid.

${ }^{23}$ Zudan Arif Fakrulloh. Op. Cit., hal. 185.
}

menentukan khususnya dalam menyelenggarakan berbagai peran dan fungsinya yakni; tidak hanya sebagai sarana artikulasi kepentingan politik saja, akan tetapi juga sebagai sarana komunikasi politik dimana arus informasi dalam suatu negara bersifat dua arah, yang artinya berjalan dari bawah ke atas. Sehingga, kedudukan partai politik dalam arus ini adalah sebagai jembatan antara "mereka yang memerintah" dan "mereka yang diperintah". ${ }^{24}$

Partai politik juga menempatkan urgensinya dalam pemilihan umum, dimana pemilihan umum tidak akan pernah terpisah dari partai politik. Para kandidat ataupun kontestan yang nantinya akan menduduki suatu jabatan di negara ini seperti jabatan di kekuasaan eksekutif (Presiden dan Wakil Presiden, Gubernur dan wakilnya, Bupati dan wakilnya, maupun Walikota dan wakilnya) serta jabatan di kekuasaan legisatif (DPR dan DPD).

Sistem politik di Indonesia telah menempatkan partai politik sebagai pilar utama penyelenggaraan demokrasi di Indonesia, artinya tidak tak ada demokrasi tanpa partai politik. Oleh sebab itu sangat diperlukan sekali sebuah peraturan perundang-undangan yang berhubungan dengan partai politik yang bertujuan agar mampu menjamin partumbuhan partai politk yang baik, sehat dan profesional..$^{25}$

Dalam kedudukannya sebagai pilar demokrasi, peran partai politik dalam sistem perpolitikan nasioanal merupakan wadah seleksi kepemimpinan nasional dan daerah. Pengalaman dalam rangkaian penyelenggaraan seleksi kepemimpinan nasional dan daerah membuktikan keberhasilan partai politik sebagai pilar demokrasi. Penyelanggaraan pemilu tahun 2004 dinilai cukup berhasil oleh banyak kalangan, termasuk kalangan internasional. ${ }^{26}$ Dengan gambaran tersebut dapat dikatakan bahwa sistem perpolitikan nasional dipandang mulai sejalandan sinkron dengan

${ }^{24}$ Ibid., hal. 186.

${ }^{25}$ Ibid., hal. 67.

26 Kementerian Hukum dan Hak Asasi Manusia Republik Indonesia,"Peran Partai Politik Dalam Penyelenggaraan Pemilu Yang Aspiratif Dan De mokratis". melaluiditjenpp.kemenkumham.go.id, diakses Senin, 08 Januari 2018, Pukul 21.30 wib. 
penataan kehidupan berbangsa dan bernegara yang di dalamnya mencakup penataan partai politik yang diatur dalam undang-undang.

Peran partai politik telah memberikan kontribusi yang signifikan bagi sistem perpolitikan nasional, terutama dalam kehidupan masyarakat Indonesia yang dinamis dan sedang berubah. Jika kapasitas dan kinerja partai politik dapat ditingkatkan, maka hal ini akan berpengaruh besar terhadap peningkatan kualitas demokrasi dan kinerja sistem politik. Oleh karena itu, peran partai politk perlu ditingkatkan kapsitas, kualitas, dan kinerjanya agar dapat mewujudkan aspirasi dan kehendak rakyat dan meningkatkan kualitas demokrasi. ${ }^{27}$

Selain peran dalam perpolitikan nasional, partai politik merupakan satu-satunya organisasi politik yang berkaitan dengan pemilihan umum. Karena peran kedudukan maupun peran partai politik dalam pemilihan umum sangatlah besar untuk mencapai tujuan dalam pemilihan dan mempergunakan kekuasaan dalam pemerintahan setelah partai politik tersebut memenangkan pemilihan umum.

Pemilihan umum maupun pemilihan kepala daerah telah menempatkan posisi partai politik sebagai konstestan ataupun pengusung peserta (calon pejabat publik) dalam ajang pesta demokrasi di negara kita. Legitimasi peraturan perihal tersebut secara yuridis telah diatur di UUD NRI Tahun 1945 maupun Undang-Undang Nomor 2 Tahun 2011 Tentang Partai Politik.

Pasal 6A ayat (2) UUD NRI Tahun 1945 menyebutkan "Pasangan calon Presiden dan Wakil Presiden diusulkan oleh partai politik atau gabungan partai politik peserta pemilihan umum sebelum pelaksanaan pemilihan umum". Berdasarkan pasal tersebut, konstitusi Republik Indonesia mengamanatkan bahwa dalam hal pengusulan pasangan calon Presiden dan Wakil Presiden adalah hak konstitusional partai politik. Tidak ada kemungkinan sama sekali bagi pasangan calon Presiden dan Wakil Presiden perseorangan atau independen di luar dari yang diusulkan oleh

\footnotetext{
${ }^{27}$ Ibid.
}

organisasi politik yang dikenal dengan partai politik.

Pasal 12 huruf i Undang-Undang Nomor 2 Tahun 2011 Tentang Partai Politik juga menjelaskan bahwa partai politik berhak mengusulkan pasangan calon Presiden dan Wakil Presiden, calon gubernur dan wakil gubernur, calon bupati dan wakil bupati, serta calon walikota dan wakil walikota sesuai dengan peraturan perundangundangan. Berdasarkan peraturan yang telah disebutkan, baik dalam konstitusi maupun undangundang, hak untuk mengsulkan pasangan calon presiden dan wakil presiden adalah mutlak hak konstitusional dari partai politik.

UUD NRI Tahun 1945 memberi peran yang besar kepada partai politik di mana partai politik adalah satu-satunya lembaga yang diberi hak sebagai pengusul pasangan calon Presiden dan Wakil Presiden. Dalam melaksanakan haknya, apabila masing-masing partai politik mengusulkan pasangan calon Presiden dan Wakil Presiden diperkirakan akan mengalami kesulitan karena sistem kepartaian yang kita anut dewasa ini adalah multipartai. Oleh karena itu, biasanya sebuah partai politik akan bekerjasama atau berkoalisi dengan partai politik lain agar dapat mengusulkan pasangan calon Prresiden dan Wakil Presiden dengan kalkulasi kekuatan menjadi lebih besar dan peluang memenangkan calon yang diusung menjadi lebih besar juga. Gabungan partai politik pengusung calon tersebut dapat berjumlah dua partai, namun bisa lebih dari dua partai. ${ }^{28}$

Calon Presiden dan Wakil Presiden yang diusulkan gabungan partai politik dapat berasal dari satu partai politik saja, biasanya dari partai politik besarraksasa yang mendominasi gabungan partai politik tersebut. Namun bisa juga calon Presiden diusulkan dari Partai A dan calon Wakil Presiden dari Partai B di mana Partai A dan Partai B merupakan anggota gabungan partai tersebut. Hal ini bisa terjadi apabila kekuatan Partai A dan Partai B relative tidak jauh berbeda. Apabila gabungan partai politik lebih dari dua partai, selain partai atau partai-partai pengusul calon Presiden dan Wakil

\footnotetext{
${ }^{28}$ Patrialis Akbar, Op.Cit., hal. 125.
} 
Presiden, terdapat partai atau partai-partai yang memberikan dukungan atas pasangan calon Presiden dan Wakil Presiden yang telah ada. Namun demikian UUD 1945 tetap membuka kemungkinan pasangan calon Presiden dan Wakil Presiden diusulkan hanya oleh satu partai saja. ${ }^{29}$

UUD NRI Tahun 1945 tidak mengatur asal usul pasangan calon Presiden dan Wakil Presiden yang diusulkan partai politik, apakah harus pengurus atau fungsionaris partai atau bisa orang di luar partai tersebut. Atas dasar itu partai politik bebas menentukan pasangan calon yang diusulkannya, bisa berasal dari kalangan internal partai tersebut dan partai lain (nonpartai politik). ${ }^{30}$

Partai politik dalam hal ini dapat merekrut seseorang yang dinilai memiliki integritas maupun kapabilitas sebagai seorang pemimpin atau sebagai calon Presiden atau Wakil Presiden. Selain itu, calon kandidat yang nantinya akan diusungkan menjadi calon Presiden atau Wakil Presiden juga dinilai oleh partai politik memiliki ketenaran ataupun banyak dikenal oleh segala kalangan ataupun lapisan masyarakat.

Dalam sistem politik yang bersifat multi-partai, koalisi adalah sebuah keniscayaan. Asumsi bahwa bahwa koalisi partai politik didorong oleh hasrat untuk mendapatkan kekuasaan baik di ranah eksekutif maupun legislatif (office seeking). Partaipartai politik kemudian merumuskan strategi pencapaian kekuasaan tersebut melalui formulasi minimalis yang biasa disebut sebagai Minimal Winning Coalition (MWC). Untuk mencapai posisi mayoritas cukup menguasi $50 \%+1$ kursi di parlemen. Dengan demikian target utamanya adalah koalisi dengan partai-partai yang memiliki kursi besar, dan tidak merasa perlu untuk melibatkan partai-partai kecil. ${ }^{31}$

${ }^{29}$ Ibid., hal. 126.

${ }^{30}$ Ibid.

31 R. Widya Setiabudi Sumadinata. "Dinamika Koalisi Partai-Partai Politik di Indonesia Menjelang dan Setelah Pemilihan Presiden Tahun 2014".Jurnal Wacana Politik. Vol. 1 No. 2, Pada Oktober 2016, hal. 184.
Tabel 1 Koalisi Partai Politik pada Pemilu $2014^{32}$

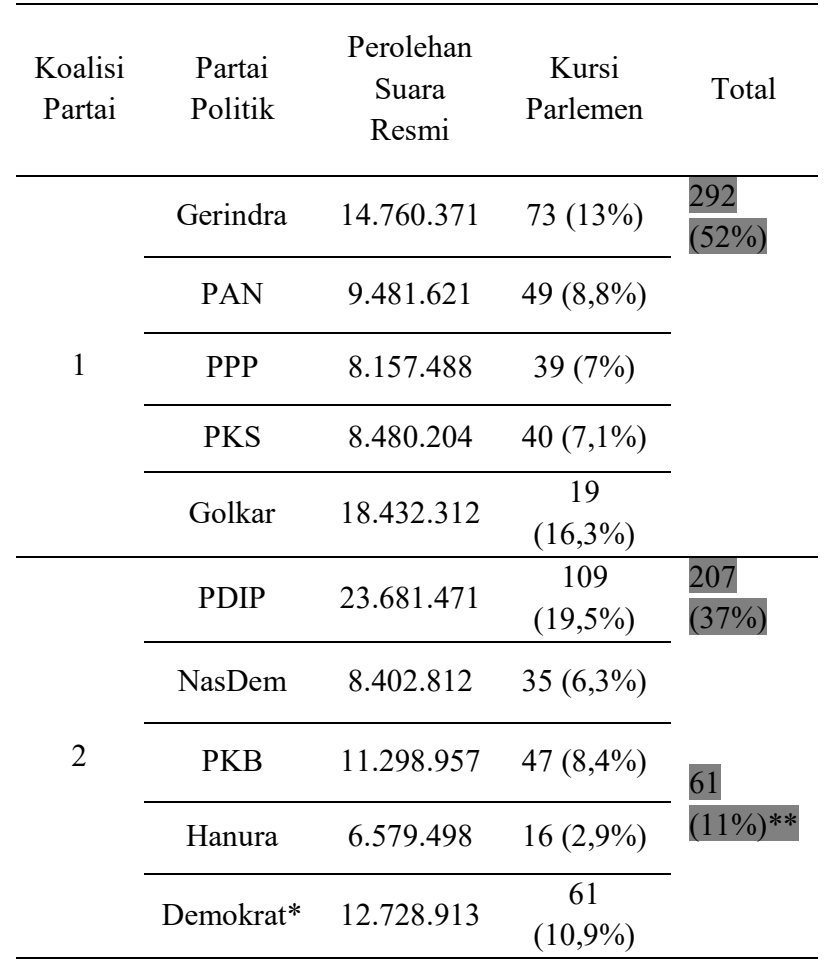

Berdasarkan tabel di atas pada pemilu Presiden dan Wakil Presiden tahun 2014 antara satu partai politik berkoalisi dengan partai politik lainnya untuk mengusung pasangan calon Presiden dan Wakil Presiden. Dan akibatnya hanya muncul 2 (dua) kandidat pasangan calon Presiden dan Wakil Presiden pada pilpres 2014 yaitu pasangan Prabowo-Hatta dan pasangan Jokowi-JK.

Sebelum menjadi peserta dalam pemilihan umum, terlebih dahulu partai politik haruslah mempunyai syarat dan mendaftarkan partainya kepada Komisi Pemilihan Umum (KPU) sebagai partai politik peserta pemilu. Persyaratan untuk menjadi partai politik peserta pemilu diatur dalam Pasal 173 ayat (2) UU No. 7 Tahun 2017 tentang Pemilihan Umum, yakni:

1. berstatus badan hukum sesuai dengan Undang-Undang Partai Politik;

2. memiliki kepengurusan di seluruh Indonesia;

32 Leo Agustino. "Pemilihan Umum di Indonesia Tahun 2014". Jurnal Prisma. Vol. 33. No. 1. Pada 2014, hal. 123. 
3. Memiliki kepengurusan di 75\% (tujuh puluh lima persen) jumlah kabupaten/kota di provinsi yang bersangkutan;

4. Memiliki kepengurusan di 50\% (lima puluh persen) jumlah kecamatan di kabupaten/kota yang bersangkutan;

5. Menyertakan paling sedikit 30\% (tiga puluh persen) keterwakilan perempuan pada kepengurusan partai politik tingkat pusat;

6. Memiliki anggota sekurang-kurangnya 1.000 (seribu) orang atau 1/1.000 (satu per seribu) dari jumlah Penduduk pada pengurusan partai politik sebagaimana dimaksud pada huruf c yang dibuktikan dengan kepemilikan kartu tanda anggota;

7. Mempunyai kantor tetap untuk kepengurusan pada tingkat pusat, provinsi, dan kabupaten/kota sampai tahapan terakhir Pemilu;

8. Mengajukan nama, lambang, dan tanda gambar partai politik kepada KPU; dan

9. Menyerahkan nomor rekening dana Kampanye Pemilu atas nama partai politik kepada KPU. ${ }^{33}$

Pendaftaran partai politik sebagai partai politik peserta pemilihan umum juga diatur dalam Pasal 176 Undang-Undang Pemilu, yakni:

1. Partai politik dapat menjadi Peserta Pemilu dengan mengajukan pendaftaran untuk menjadi calon Peserta Pemilu kepada KPU.

2. Pendaftaran sebagaimana dimaksud pada ayat (1) diajukan dengan surat yang ditandatangani oleh ketua umum dari sekretaris jenderal atau nama lain pada kepengurusan pusat partai politik.

3. Pendaftaran sebagaimana dimaksud pada ayat (2) disertai dokumen persyaratan yang lengkap.

4. Jadwal waktu pendaftaran Partai Politik Peserta Pemilu ditetapkan oleh KPU

${ }^{33}$ Lihat Pasal 173 ayat (2) Undang-Undang Nomor 7 Tahun 2017 Tentang Pemilu. paling lambat 18 (delapan belas) bulan sebelum hari pemungutan suara. ${ }^{34}$

Setelah pendaftaran sebagai partai politik peserta pemilu, partai politik akan mengikuti langkah selanjutnya yaitu verifikasi. Verifikasi partai politik calon peserta pemilu diatur dalam Pasal 178 UU Pemilu, yakni:

1. KPU melaksanakan penelitian administrasi dan penetapan keabsahan persyaratan sebagai mana dimaksud Pasal 173 ayat (2) terhadap Partai Politik yang mengikuti verifikasi dengan dokumen persyaratan sebagaimana dimaksud dalam Pasal 177.

2. Verifikasi sebagaimana dimaksud pada ayat (1) harus selesai dilaksanakan paling lambat 14 (empat belas) bulan sebelum hari pemungutan suara.

3. Ketentuan lebih lanjut mengenai pelaksanaan dan waktu verifikasi sebagaimana dimaksud pada ayat (1) dan ayat (2) diatur dengan Peraturan KPU.

4. Ketentuan mengenai tata cara penelitian administrasi dan penetapn keabsahan persyaratan sebagaimana dimaksud pada ayat (1) diatur dengan peraturan KPU. ${ }^{35}$

Partai politik calon peserta pemilu yang lulus dalam verifikasi akan ditetapkan sebagai partai politik peserta pemilihan umum oleh KPU. Kemudian nomor urut partai politik sebagai peserta pemilu akan diundi dalam sidang pleno KPU yang terbuka dan dihadiri oleh wakil partai politik peserta pemilu. ${ }^{36}$

Dewasa ini partai politik dinilai belum mampu melahirkan kader-kader politiknya yang dinilai memiliki kemampuan untuk memimpin negara dan membela kepentingan rakyat, dikarenakan ada kelemahan dalam oraganisasi partai politik. Oragnisasi dan termasuk juga organisasi partai politik, kadang-kadang bertindak dengan lantang

\footnotetext{
${ }^{34}$ Lihat Pasal 176 Undang-Undang Nomor 7 Tahun 2017 Tentang Pemilu.

${ }^{35}$ Lihat Pasal 178 Undang-Undang Nomor 7 Tahun 2017 Tentang Pemilu.

${ }^{36}$ Lihat Pasal 179 Undang-Undang Nomor 7 Tahun 2017 Tentang Pemilu.
} 
untuk dan atas nama kepentingan rakyat, tetapi dalam kenyataannya justru berjuang untuk kepentingan pengurusnya sendiri. ${ }^{37}$ Maka dari itu sering muncul istilah janji manis partai politik.

Partai politik sebagai pemegang hak konstitusional dalam pengusulan pasangan calon Presiden dan Wakil Presiden dalam pemilihan umum, diharapkan mampu menghadirkan sosok pemimpin negara yang memiliki integritas maupun kapabilitas melalui fungsi partai politik sebagai organisasi maupun lembaga pengkaderan dan pemberian pendidikan politik bagi calon-calon pemimpin bangsa kelak. Dan yang terpenting, pemimpin yang dilahirkan partai politik tidak terpaku keras terhadap kepentingan partainya melainkan kepentingan seluruh masyarakat.

\section{Pengusulan Pasangan Calon Presiden Dan Wakil Presiden Dengan Sistem Ambang Batas Pencalonan Presiden Dan Wakil Presiden}

Tipe demokrasi yang ideal diwujudkan dalam derajat yang berbeda-beda melalui konstitusi yang berbeda-beda pula. Demokrasi langsung adalah demokrasi dengan derajat yang relatif paling tinggi. ${ }^{38}$ Setiap negara yang ada di dunia ini ratarata menganggap bahwa negaranya adalah penganut sistem demokrasi. Dimana demokrasi adalah prisnsip yang menjunjung tinggi kedaulatan rakyat yaitu dari rakyat, noleh rakyat, dan untuk rakyat. Salah satu prosedur dalam demokrasi tersebut adlah pemilihan umum atau yang dikenal dengan pemilu.

Pemilihan umum yaitu sarana pesta demokrasi bagi rakyat ataupun warga negara untuk memilih dan menentukan wakil-wakil rakyat yang akan duduk di pemerintahan, baik parlemen maupun eksekutif. Hal ini juga diterapkan di negara Indonesia dimana rakyat Indonesia memilih dan menentukan wakil-wakilnya yang akan duduk dalam parlemen juga eksekutif melalui pemilihan umum.

37 Jimly Asshiddiqie. 2016. Konstitusi Bernegara. Jawa Timur: Setara Press, hal. 213.

${ }^{38}$ Hans Kelsen. 2016. Teori Umum Tentang Hukum Dan Negara. Bandung: Nusa Media, hal. 408.
Pentingnya pemilu juga dapat dikaitkan dengan kenyataan bahwa setiap jabatan pada pokoknya berisi tanggung jawab yang harus dilaksanakan oleh manusia yang mempunyai kemampuan terbatas. Karena itu, pada prinsipnya setiap jabatan harus dipahami sebagai amanah yang bersifat sementara. Jabatan bukan harus dinikmati dan untuk selama-lamanya. Oleh karena itu, seseorang tidak boleh duduk disuatu jabatan tanpa batas yang pasti mengenai waktu pergantiaanya. Tanpa siklus yang dinamis kekuasan mengeras menjadi sumber malapetaka sesuai dengan adagium yang dikemukakan oleh Lord Acton, "Power tend to corrupt, absolute power corrupt absolutely". Karena dalam jabtan selalu ada kekuasaan yang cenderung berkembang menjadi sumber kesewenang-wenangan bagi siapa saja yang memegangnya. Karena itu, pergantian kepemimpinan itu harus dipandang sebagaisuatu yang niscaya untuk memlihara amanah yang terdapat dalam setiap kekuasaan itu sendiri. ${ }^{39}$

Disamping itu, pemilihan umum itu juga penting bagi para wakil rakyat maupun pejabat pemerintahan untuk mengukur legitimasi atau tingkat dukungan dan kepercayaan masyarakat kepadanya. Menjadi pejabat publik tidak hanya memerlukan legalitas secara hukum, tetapi juga legitimasi secara politik, sehinnga tugas jabatan dapat dilaksanakan dengan sebaik-baiknya, karena diakui, diterima dan dipercaya oleh rakyat sebagai pemangku kepentingan yang terkait (stake holder). Demikian pula bagi kelompok warga negara yang tergabung dalam suatu organisasi partai politik, pemilihan umum juga penting untuk mengetahui seberapa besar tingkat dukungan dan kepercayaan rakyat kepada kelompok atau partai politik yang bersangkutan. ${ }^{40}$

Analisis tingkat kepercayaan dan dukungan tersebut dapat tergambar pula menegenai aspirasi rakyat yang sesungguhnya sebagai pemegang ataupun pemilik dari kedaulatan rakyat dan kekuasaan tertinggi Republik Indonesia.Sehinngga

39 Jimly Assiddhiqie.2007. Pokok-Pokok Hukum Tata Negara Indonesia. Jakarta: Bhuana Ilmu Populer, hal. 755 .

${ }^{40}$ Ibid.,hal. 757. 
nantinya segala kebijakan yang dibuat oleh pejabat publik haruslah sesungguhnya berasal dari aspirasi seluruh rakyat Indonesia.

Amandemen UUD NRI Tahun 1945 (19992002) banyak merubah sistem ketatanegaraan Indonesia, termasuk salah satunya dalam mekanisme pemilihan umum untuk memilih calon Presiden dan Wakil Presiden. Pada mulanya sebelum diamandemen, pemilihan Presiden dan Wakil Presiden dipilih oleh Majelis Permusyawaratan Rakyat (MPR). Yang secara eksplisit terletak pada Pasal 6 ayat (2) UUD 1945 sebelum diamandemen yang menyatakan, "Presiden dan Wakil Presiden dipilih oleh Majelis Permusyawaratan Rakyat dengan suara terbanyak". ${ }^{41}$

Setelah perubahan UUD 1945, ketentuan konstitusi tentang pemilihan Presiden dan Wakil Presiden dicantumkan dalam Pasal 6A ayat (1) yang menhyebutkan, "Presiden dan Wakil Presiden dipilih dalam satu pasangan secara langsung oleh rakyat". Hal ini jugalah yang membawa perubahan ketentuan dalam penyelenggaraan Pemilihan Umum Presiden dan Wakil Presiden (Pilpres) di Indonesia.

Konstitusi telah menentukan bahwa pasangan calon Presiden dan Wakil Presiden diusulkan oleh partai politik atau gabungan partai politik peserta pemilihan umum sebelum pelaksanaan pemilihan umum. ${ }^{42}$ Dengan ketentuan tersebut, maka criteria untuk pencalonan Presiden dan Wakil Presiden harus berasal dari partai politik.

Selain harus mempunyai kendaraan politik, pasangan calon Presiden dan Wakil Presiden yang ingin memenangkan pemilu pilpres harus memiliki ketentuan terhadap perolehan suara dalam pemilu. Dalam hal pasangan calon Presiden dan Wakil Presiden yang mendapatkan suara lebih dari lima puluh persen dari jumlah suara dalam pemilihan umum dengan sedikitnya dua puluh persen suara di setiap provinsi yag tersebar di lebih dari setengah

${ }^{41}$ Pasal 6A ayat (1) Undang-Undang Dasar Negara Republik Indonesia Tahun 1945.

${ }^{42}$ Pasal 6A ayat (2) Undang-Undang Dasar Negara Republik Indonesia Tahun 1945. jumlah provinsi di Indonesia, dilantik menjadi Presiden dan Wakil Presiden. ${ }^{43}$

Penyelenggaraan pemilihan umum Presiden dan Wakil Presiden di Indonesia pasca perubahan UUD NRI Tahun 1945 mengenal ketetentuan ambang batas pencalonan Presiden dan Wakil Presiden atau yang biasa diistilahkan Presidential Threshold. Ambang batas pencalonan ini digunakan sebagai prasyarat dalam pencalonan Presiden dan Wakil Presiden yang diusungkan oleh partai politik atau gabungan partai politik.

Presidential Threshold, atau lebih dikenal sebagai ambang batas pencapresan di kancah perpolitikan Indonesia adalah sebuah mekanisme yang dibuat oleh partai politik yang ingin menagajukan calonnya sendiri, untuk diadu tandingkan di Kancah Pemilu Presiden. ${ }^{44}$

Menurut pengertian selanjutnya, Presidential Threshold adalah pengaturan tingakt ambang batas dukungan dari DPR, baik dalam bentuk jumlah suara (ballot) atau jumlah perolehan kursi (seat) yang harus diperoleh partai politik peserta pemilu agar dapat mencalonkan Presiden dari partai politik tersebut atau dengan gabungan partai politik. ${ }^{45}$

Pengaturan terkait dengan ambang batas pencalonan Presiden dan wakil Presiden pertama kali diatur dalam Pasal 5 ayat (4) Undang-Undang Nomor 23 Tahun 2003 Tentang Pemilihan Umum Presiden Dan Wakil Presiden yang mnyebutkan, "Pasangan Calon Sebagaimana dimaksud pada ayat (1) hanya dapat diusulkan oleh partai politik atau gabungan partai politik yang memperoleh sekurang-kurangnya $15 \%$ (lima belas persen) dari jumlah kursi DPR atau 20\% (dua puluh persen) dari perolehan suara sah secara nasional dalam Pemilu anggota DPR.

${ }^{43}$ Pasal 6A ayat (3) Undang-Undang Dasar Negara Republik Indonesia Tahun 1945.

44 Pono Bum, "Presidential Threshold", melalui www.academia.edu, diakses Selasa, 16 Januari 2017, Pukul 12.15 wib.

45 Lutfil Ansori. "Telaah Terhadap Paresidential Threshold Dalam Pemilu Serentak 2019".Jurnal Yuridis. Vol. 4 No. 1.Pada Juni 2014, hal. 18. 
Kemudian ketentuan tersebut dirubah dan kembali diatur dalam Pasal 9 Undang-Undang Nomor 42 Tahun 2008 Tentang Pemilihan Umum Presiden dan Wakil Presiden yang menyebutkan, "Pasangan Calon diusukan oleh Partai Politik atau Gabungan Partai Politik peserta pemilu yang memenuhi persyaratan perolehan kursi paling sedikit 20\% (dua puluh persen) dari jumlah kursi DPR atau memperoleh 25\% (dua puluh lima persen) dari suara sah nasioanal dalam pemilu anggota DPR, sebelum pelaksanaan Pemilu Presiden dan Wakil Presiden".

Undang-undang a quo dirubah menjadi Undang-Undang Nomor 7 Tahun 2017 Tentang Pemilihan Umum, yang di dalam Undang-Undang Pemilu tersebut juga mengatur tentang ambang batas bagi partai politik yang akan mengsulkan calon Presiden dan Wakil Presiden. Dalam Pasal 222 Undang-Undang Pemilu menyebutkan, "Pasangan Calon diusulkan oleh Partai Politik atau Gabungan Partai Politik Peserta Pemilu yang memenuhi persyaratan perolehan kursi paling sedikit 20\% (dua puluh persen) dari jumlah kursi DPR atau memperoleh $25 \%$ (dua puluh lima persen) dari suara sah secara nasional pada pemilu anggota DPR sebelumnya".

Menganalasis sistem pencalonan Presiden dan Wakil Presiden dengan adanya ambang batas pencalonan atau Presidential Threshold yaitu partai politik atau gabungan partai politik yang dapat mengajukan pasangan calon adalah partai politik yang memperoleh suara sah paling sedikit 20 persen atau memperoleh suara sah paling sedikit 25 persen dari jumlah suara sah nasional.

Jika berdasarkan jumlah kursi berarti hitungannya 20 persen dari 560 kursi DPR atau 112 kursi. Artinya partai politik atau gabungan partai politik yang memiliki 112 kursi di DPR dapat mengajukan pasangan calon Presiden dan Wakil Presiden. ${ }^{46}$

Selain berdasarkan jumlah kursi, pengajuan pasangan calon Presiden dan Wakil Presiden dapat

46 Vhanda, "Ini Syarat dan Tata Cara Pengajuan Capres", melalui www.detiknews.com, dikses Selasa, 16 Januari 2017, Pukul 20.00 wib. dilakukan berdasarkan perolehan suara sah nasional dalam Pemilu Anggota DPR.Partai politik atau gabungan partai politik harus menebus 25 persen suara.

Untuk menentukan angka 25 persen perolehan suara sah secara nasional dalam Pemilu Anggota DPR akan diketahui setelah penetapan rekapitulasi penghitungan suara secara nasional. ${ }^{47}$ Dengan demikian ada dua cara bagi partai politik peserta pemilu agar dapat mengusulkan pasangan calon Presiden dan Wakil Presiden, baik dengan cara memperoleh suara di DPR atau legislatif sebesar 20 persen atau dengan cara mendapat suara sah nasional sebesar 25 persen.

Perolehan suara dan presentase nasional pada pemilu 2014: ${ }^{48}$

1. PDIP 23.681.471 suara $(18,95 \%)$

2. Golkar 18.432 .312 suara $(14,75 \%)$

3. Gerindra 14.760 .371 suara $(11,81 \%)$

4. Demokrat 12.728 .913 suara $(10,9 \%)$

5. PKB 11.298.950 suara $(9,04 \%)$

6. PAN 9.481.621 suara $(7,59 \%)$

7. PKS 8.480 .488 suara $(6,79 \%)$

8. Nasdem 8.402 .812 suara $(6,79 \%)$

9. PPP 8.157 .488 suara $(6,53 \%)$

10. Hanura 6.579 .498 suara $(5,26 \%)$

11. PBB 1.825 .750 suara $(1,46 \%)$

12. PKPI 1.143 .094 suara $(0,91 \%)$

Jika melihat presentase hasil pemilu 2014 di atas, tidak ada satu partai politikpun yang memenuhi ambang batas suara sah nasional untuk mengusulkan pasangan calon Presiden dan Wakil Presiden dalam pilpres. Maka dari itu koalisi atau bergabung antara satu partai politik dengan partai politik lain merupakan cara untuk bisa memenuhi ambang batas ataupun presidential threshold.

Sebelum menjadi konstestan dalam pemilihan umum Presiden dan Wakil Presiden, terlebih dahulu partai politik atau gabungan partai politik harus mendaftarkan Pasangan Calon Presiden dan

$$
{ }^{47} \mathrm{Ibid} \text {. }
$$

${ }^{48}$ No Name, "KPU Sahkan Hasil Pemilu, PDIP Nomor Satu", melalui www.bbc.com, diakses Selasa, 16 Januari 2017, Pukul 22.30 wib. 
Wakil Presiden yang diusungnya, pendaftaran tersebut diataur dalam Pasal 226 Undang-Undang Pemilu, yakni: ${ }^{49}$

1. Bakal Pasangan Calon didaftarkan oleh Partai Politik atau Gabungan Partai Politik yang telah ditetapkan oleh KPU sebagai Peserta Pemilu.

2. Pendaftaran bakal Pasangan Calon oleh Partai Politik ditandatangani oleh ketua umum atau nama lain dan sekretaris jenderal atau nama lain serta Pasangan Calon yang bersangkutan.

3. Pendaftaran bakal Pasangan Calon oleh Gabungan Partai Politik ditandatangani oleh ketua umum atau nama lain dan sekretaris jenderal atau nama lain dari setiap Partai Politik yang bergabung serta Pasangan Calon yang bersangkutan.

4. Masa pendaftaran bakal Pasangan Calon paling lama 8 (delapan) bulan sebelum hari pemungutan suara.

Para pejabat negara yang akan maju sebagai calon Presiden atau calon Wakil Presiden harus mengundurkan diri dari jabatannya. Sementara bagi kepala daerah yang akan maju sebagai calon Presiden atau Wakil Presiden seperti gubernur, bupati, wakil bupati, wali kota, dan wakil walikota, harus meminta izin kepada Presiden. ${ }^{50}$

Bila dikaji lebih dalam, sebenarnya kebijakan presidential threshold terkait dengan kebijakan ambang batas parlemen atau parlmentary threshold yang menggantikan electoral threshold. Presidential threshold ini menjadi salah satu cara penguatan sistem presidensial melalui penyederhanaan partai politik. Tujuannya menciptakan pemerintahan yang stabil dan tidak menyebabkan pemerintahan yang berjalan mengalami kesulitan di dalam mengambil kebijakan dengan lembaga legislatif. ${ }^{51}$

Disatu sisi, peraturan ambang batas ini memiliki nilai positif, yaitu untuk memastikan presiden

${ }^{49}$ Lihat Pasal 226 Undang-Undang Nomor 7 Tahun 2017 Tentang Pemilihan Umum.

${ }^{50}$ Vhanda, Log., Cit.

${ }^{51}$ Lutfil Ansori, Op., Cit. hal. 19. mendapatkan dukungan dari suara mayoritas di parlemen saat dia menjalankan roda pemerintahan. Selain itu dengan adanya peraturan ini dapat menguntungkan bagi pemerintah yang akan terbentuk, yaitu:

1. Bagi parpol akan menjadikan koalisi sebagai penyatuan kekuatan atau dengan kata lain memperkuat parpol dan parlemen, ibarat sapu lidi yang satu demi satu setelah digabung menjadi satu akan kuat dan kokoh.

2. Akan mampu mewakili berbagai kepentingan di dalam parpol itu sendiri. Istilah bagi hasil nantinya jika sudah menang.

3. Dengan adanya koalisi akan mendukung jalannya pemerintahan, yaitu kebijakankebijakan pemerintah akan mudah untuk direalisasikan sehingga tercipta kerjasama yang baik untuk kemajuan negara.

4. Meningkatkan dan memperbaiki mekanisme serta prosedur rekruitmen pejabat publik.

5. Memperkuat sistem presidensial setelah terealisasi sistem multi-partai sederhana. ${ }^{52}$

Secara teoritis, dalam sistem presidensial aspek dukungan lembaga legislatif menjadi hal yang sangat penting. Sistem presidensial akan menjadi kuat, manakala mendapat dukungan yang memadai di legilatif. Oleh karena itu, berbicara penguatan sistem presidensial adalah berbicara mengenai peningkatan dukungan politik di legislatif.

Dalam salah satu hasil publikasi penelitiannya, Jones menyatakan “...all evidence indicates of functioning of presidential system is greatly enhanced when the president is provided whit a majority or near-majority in the legislature." Dengan kata lain, memperkuat sistem presidensial sangat terkait dengan tersedianya dukungan politik yang memadai di lembaga legislatif bagi seorang Presiden. Dukungan yang memadai itu dimaknai secara operasional sebagai dukungan mayoritas (50 persen lebih) atau hampir mayoritas (mendekati 50 persen). Apabila seorang Presiden memiliki

52 Pono Bum, Log., Cit. 
dukungan kurang dari ambang batas tersebut, maka sulit bagi seorang Presiden untuk menjalankan agenda-agenda pemerintahannya. Akibat selanjutnya adalah kurang atau tidak berfungsinya sistem presidensial, atau lebih buruk lagi bisa berujung pada kegagalan pemerintahan. ${ }^{53}$

Penerapan presidential threshold mengandung konsekuensi hilangnya kesmepatan dan hak warga negara melalui partai politik yang tidak memenuhi besaran angka yang ditentukan untuk mengajukan calonnya. Oleh karena itu perlu diperhatikan, sesuai dengan prinsip demokrasi, dalam penentuan ambang batas besaran presidential threshold tidak boleh merugikan kelompok masyarakat tertentu terutama minoritas. Penentuan ambang batas presidential threshold harus memperhatikan keragaman masyarakat yang tercermin dalam aspirasi politik. ${ }^{54}$

Penentuan presidential threshold tersebut perlu diperhatikan secara proporsional serta memperhatikan keseimbangan antara politik hukum penyederhanaan partai politik. Penentuan besaran ambang batas presidential threshold tidak boleh dilakukan berdasarkan pertimbangan keuntungan dan kerugian yang akan didapat oleh partai politik. $^{55}$

\section{Hak Konstitusional Partai Politik Dalam Mengusulkan Pasangan Calon Presiden Dan Wakil Presiden Dengan Adanya Ambang Batas Pencalonan Presiden Dan Wakil Presiden}

Pancasila yang terdiri atas lima sila pada hakikatnya merupakan sistem filsafat. Sistem adalah suatu kesatuan dari bagian-bagian yang saling berhubungan, saling bekerja sama untuk satu tujuan tertentu dam secara keseluruhan merupakan suatu kesatuan yang utuh, sistem lazimnya memiliki ciri-ciri sebagai berikut:

1. Suatu kesatuan bagian-bagian;

2. Bagian-bagian tersebut mempunyai fungsi sendiri-sendiri;

${ }^{53}$ Ni'matul Huda. M. Imam Nasef. 2017. Penataan Demokrasi dan Pemilu di Indonesia Pasca Reformasi. Jakarta: Kencana, hal. 261.

${ }^{54}$ Lutfil Ansori, Log., Cit.

${ }^{55}$ Ibid.
3. Saling berhubungan, saling ketergantungan;

4. Kesemuanya dimaksudkan untuk mencapai suatu tujuan bersama (tujuan sistem);

5. Terjadi dalam suatu lingkungan yang kompleks. ${ }^{56}$

Pancasila yang terdiri atas bagian-bagian yaitu sila-sila Pancasila, setiap sila pada hakikatnya merupakan suatu asas sendiri, Fungsi sendirisendiri untuk tujuan tertentu, yaitu suatu masyarakat yang adil dan makmur berdasarkan Pancasila. ${ }^{57}$ Sebagai contoh sila keempat Pancasila yang berbunyi, Kerakyatan yang dipimpin oleh hikmat kebijaksanaan dalam permusyawaratan/perwakilan. Sila tersebut mengandung makna nilai demokrasi yang secara mutlak harus dilaksanakan dalam hidup bernegara yang juga menyangkut aspek moralitas kenegaraan, aspek politik, maupun aspek hukum dan perundang-undangan.

Dalam suatu negara demokrasi, pemilu dilaksanakan secara teratur. Setiap warga negara yang sudah dewasa mempunyai hak untuk memilih dan dipilih serta bebas menggunakan haknya tersebut sesuai dengan kehendak hati nuraninya. Dia bebas untuk menentukan partai atau calon mana yang akan didukungnya, tanpa ada rasa takut atau paksaan dari orang lain. Pemilih juga bebas mengikuti segala macam aktifitas pemilihan, termasuk didalamnya kegiatan kampanye dan menyaksikan perhitungan suara. ${ }^{58}$

Tatkala demokrasi secara khusus dikaitkan dengan pemilu, dipahami bahwa Pasal 2 ayat (1) Undang-Undang Dasar Negara Republik Indonesia Tahun 1945 mennyatakan bahwa "kedaulahtan berada di tangan rakyat dan dilaksanakan menurut Undang-Undang Dasar". Maka dari "kedaulatan berada ditangan rakyat" dalam hal ini ialah bahwa rakyat memiliki kedaulatan, tanggung jawab, hak

56 Ani Sri Rahayu. 2014. Pendidikan Pancasila \& Kewarganegaraan (PPKn). Jakarta: Bumi Aksara, hal. 9.

${ }^{57}$ Ibid.

58 Arsyad Sanusi. 2011. Tebaran Pemikiran Hukum dan Konstitusi. Jakarta: Milestone, hal. 870. 
dan kewajiban untuk secara demokratis memilih pemimpin yang akan membentuk pemerintahan guna mengurus dan melayani seluruh lapisan masyarakat, serta memilih wakil-wakil rakyat untuk mengawasi jalannya pemerintahan. Perwujudan kedaulatan rakyat dimaksud dilaksanakan melalui pemilihan umum secara langsung sebagai sarana bagi rakyat untuk memilih wakil-wakilnya yang akan menjalankan fungsi melakukan pengawasan, menyalurkan aspirasi politik rakyat, membuat undang-undang sebagai landasan bagi semua pihak di Negara Kesatuan Republik Indonesia dalam menjalankan fungsi masing-masing, serta merumuskan anggaran pendapatan dan belanja untuk membiayai pelaksanaan fungsi-fungsi tersebut. ${ }^{59}$

Pasal 22E ayat (2) UUD NRI Tahun 1945 menyatakan bahwa, pemilihan umum diselenggarakan untuk memilih anggota Dewan Perwakilan Rakyat, Dewan Perwakilan Daerah, Presiden dan Wakil Presiden dan Dewan Perwakilan Rakyat Daerah. Pemilihan umum dimaksud diselenggarakan dengan menjamin prinsip keterwakilan, yang artinya setiap warga negara memiliki wakil yang duduk di lembaga perwakilan atau parlemen juga menjamin memiliki pemimpin bangsa yang dinilai mampu untuk menjalankan roda pemerintahan guna mewujudkan kesejahteraan bagi seluruh rakyat.

Pemilihan umum maupun pemilihan kepala daerah telah menempatkan posisi partai politik sebagai konstestan ataupun pengusung peserta (calon pejabat publik) dalam ajang pesta demokrasi di negara kita. Undang-Undang Dasar Negara Republik Indonesia telah memberikan hak konstitusional bagi partai politiik sebagai peserta pemilihan umum.

Pasal 6A ayat (2) UUD NRI Tahun 1945 yang menyatakan bahwa, pasangan calon Presiden dan Wakil Presiden diusulkan oleh partai politik atau gabungan partai politik peserta pemilihan umum sebelum pelaksanaan pemilihan umum. ${ }^{60}$ Kemudian dalam Pasal 22E ayat (3) juga

${ }^{59}$ Ibid., hal. 874.

${ }^{60}$ Lihat Pasal 6A ayat (2) UUD NRI Tahun 1945. menyatakan bahwa, peserta pemilihan umum untuk memilih anggota Dewan Perwakilan Rakyat dan anggota Dewan Perwakilan Rakyat Daerah adalah partai politik. ${ }^{61}$ Dari ketentuan tersebut telah melegitimasi bahwa dalam pemilu untuk memilih Presiden dan Wakil Presiden maupun pemilu anggota DPR dan DPRD adalah hak partai politik untuk mengusulkan calonnya, terkecuali dalam pemilihan anggota DPD.

Penyelenggaraan pemilihan umum Presiden dan Wakil Presiden di Indonesia pasca perubahan UUD NRI Tahun 1945 mengenal ketentuan ambang batas pencalonan Presiden dan Wakil Presiden atau Presidential Threshold. Ambang batas pencalonan ini digunakan sebagai prasyarat dalam pencalonan Presiden dan Wakil Presiden yang diusungkan oleh partai politik atau gabungan partai politik Ketentuan ambang batas tersebut mengharuskan partai politik peserta pemilihan umum harus memperoleh suara di kursi legislatif sebesar 20 persen atau harus memperoleh 25 persen suara sah nasional pada pemilihan umum sebelumnya apabila partai politik tersebut ingin mengusulkan pasangan calon Presiden dan Wakil Presiden sesuai dengan ketentuan dalam Pasal 222 UU Pemilu.

Peraturan mengenai ambang batas tersebut jika ditelaah akanmerestriksi ataupun membatasi hakhak konstitusional partai poitik dalam mengusulkan pasangan calon Presiden dan Wakil Presiden. Partai politik yang tak cukup suaranya sesuai ketentuan ambang batas, tidak akan bisa untuk mengusulkan pasangan calon Presiden dan Wakil Presiden. Lebih memiluhkan lagi, bagaimana dengan nasib partai politik baru yang baru pertama kali akan ikut dalam pemilihan umum Presiden dan Wakil Presiden nantinya. Tentu sudah diketahui bahwa suara partainya adalah 0 (nol) persen. Dan juga mereka tak sama sekali memiliki kesempatan untuk mengusulkan pasangan calon Presiden dan Wakil Presiden pada ajang Pemilu Presiden dan Wakil Presiden.

Pasal 6A ayat (2) UUD NRI Tahun 1945 telah mengamanatkan bahwa pasangan calon Presiden dan Wakil Presiden diusulakan oleh partai politik

\footnotetext{
${ }^{61}$ Lihat Pasal 22A ayat (3) UUD NRI Tahun 1945.
} 
atau gabungan partai peserta pemilihan umum sebelum pelaksanaan pemilihan umum. Disini Pasal 6A ayat (2) UUD NRI Tahun 1945 apabila tidak ditafsirkan lain, maka pemberlakuaanya tanpa ada hambatan. Sesuai dengan Pasal 6A ayat (2) UUD NRI Tahun 1945 dengan pemilu serentak, maka setiap partai politik peserta pemilihan umum dapat mengajukan pasangan calon Presiden dan Wakil Presiden tanpa syarat mempunyai sejumlah kursi tertentu di DPR. ${ }^{62}$

Sebenarnya Pasal 6A UUD 1945 tidak menentukan adanya ambang batas (presidential threshold) dalam Pemili Presiden dan Wakil Presiden, yang ada hanyalah "pasangan calon Presiden dan calon Wakil Presiden diajukan oleh partai politik atau gabungan partai politik peserta pemilu". Asumsi bahwa apabila sebuah partai politik secara hukum menjadi peserta pemilu berarti berhak mengajukan pasangan calon Presiden dan calon Wakil Presiden tanpa harus ada syarat ambang batas (presidential threshold) ${ }^{63}$

Pasal 6A ayat (2) UUD NRI Tahun 1945 mengandung makna bahwa persyaratan yang berlaku bagi capres dan wapres adalah:

1. Capres dan wapres diajukan oleh partai politik baik sendiri-sendiri maupun bersama-sama dalam gabungan/koalisi partai politik;

2. Semua partai politik dapat mengajukan pasangan capres dan wapres sepanjang memenuhi persyaratan sebagahi peserta pemilu; dan

3. Tidak ada penambahan syarat lain berupa threshold berapa pun besarnya. ${ }^{64}$

Berkaca juga pada Pasal 28C ayat (2) yang menyatakan bahwa, setiap orang berhak untuk memajukan dirinya dalam memperjuangkan haknya secara kolegtif untuk membangun masyarakat, bangsa, dan negaranya. Apabila dihubungkan dengan ketentuan ambang batas (presidential threshold), maka orang-orang yang memiliki integritas sebagai pemimpin yang

\footnotetext{
${ }^{62}$ Lutfil Ansori, Op., Cit. hal. 22.

${ }^{63}$ Sodikin, Op., Cit. hal. 27.

${ }^{64}$ Lutfil Ansori, Log., Cit.
}

memiliki tujuan untuk membangun negara dan mensejahterakan rakyat dan akan diusulkan untuk menjadi calon Presiden atau Wakil Presiden oleh partai politik maka akan terhalang tujuannya tersebut apabila partai politik pengusungnya tidak memenuhi ketentuan dalam ambang batas.

Kemudian menilik juga pada Pasal 28D ayat (1) yang menyatakan bahwa, setiap orang berhak atas pengakuan, jaminan, perlindungan, dan kepastian hukum yang adil serta perlakuan yang sama di hadapan hukum. Berdasarkan ketentuan tersebut jika dikaitkan dengan presidential threshold, sesungguhnya presidential threshold telah menciderai keadilan bagi warga negara lewat pembatasan yang dibuatnya kepada partai politik peserta pemilu.

Dua prinsip keadila yang dikemukakan oleh John Rawls, yaitu: ${ }^{65}$

Pertama: setiap orang mempunyai hak yang sama atas kebebasan dasar yang paling luas, seluas kebebasan yang sama bagi semua orang; Kedua: ketimpangan sosial dan ekonomi mesti diatur sedemikian rupa sehinnga (a) dapat diharapkan member keuntungan semua orang, dan (b) semua posisi jabatan terbuka bagi semua orang.

Apabila dua prinsip keadilan yang dikemukakan oleh John Rawls itu dikomparasikan dengan sistem ambang batas pencalonan atau presidential threshold, maka sesungguhnya ambang batas dalam mengajukan calon Presiden dan Wakil Presiden sangat bertolak belakang dengan prinsipprinsip keadilan tersebut. Yang pertama dalam pemberian kebebasan terkait pencalonan Presiden dan Wakil Presiden oleh partai politik dan yang kedua akan memberikan keuntungan sepihak saja apabila ambang batas ini tetap diberlakukan dalam pemilihan umum Presiden dan Wakil Presiden.

Ambang batas pencalonan Presiden dan Wakil Presiden sudah tiga kali diuji atau di jucial review ke Mahkamah Konstitusi dikarenakan banyak pihak yang merasa hak konstitusionalnya dibatasi terutama partai politik peserta pemilihan umum.

\footnotetext{
65 John Rawls. 2011. Teori Keadilan. Yogyakarta: Pustaka Pelajar, hal. 72.
} 
Pertama kali norma atau pengaturan ambang batas ini di judicial review pada uji materil Pasal 9 Undang-Undang Nomor 42 Tahun 2008 tentang Pemilihan Umum Presiden dan Wakil Presiden. Dalam putusannya Nomor 51-52-59/PUU-VI/2008, Mahkamah memutuskan terkait ambang batas (presidential threshold) adalah konstitusional atau tidak bertentangan dengan UUD NRI Tahun 1945.

Mahkamah Konstitusi dalam purtusan Nomor 51-52-59/PUU-VI/2008 berpendapat bahwa, norma ambang batas merupakan delegasi kewenangan terbuka yang dapat ditentukan sebagai legal policy oleh pembentuk undang-undang. Meskipun seandainya isi suatu undang-undang dinilai buruk, seperti halnya ketentuan presidential threshold, Mahkamah tetap tidak dapat membatalkannya, sebab yang dinilai buruk tidak selalu berarti inkonstitusional, terkecuali kalau produk legal policy tersebut jelas-jelas melanggar moralitas, rasionalitas dan ketidakadilan yang intolerable. ${ }^{66}$

Pendapat berbeda (dissenting opinion) oleh tiga hakim konstitusi yaitu Abdul Mukhtie Fajar, Maruarar Siahaan, dan M. Akil Mochtar berpendapat bahwa ambang batas dalam pencalonan Presiden dan Wakil Presiden adalah inkonstitusional. Mereka berpendapat bahwa dalam Pasal 6A ayat (2) UUD NRI Tahun 1945 sebenarnya sudah sangat jelas maksudnya dan tidak member peluang bagi pembentuk undang-undang membuat kebijakan hukum (legal policy) dengan "akal-akalan" yang terkontaminasi motif politik ad hoc menentukan presidential threshold. Alasan penggunaan Pasal 6A ayat (5) yang berbunyi, "Tata cara pelaksanaan pemilihan Presiden dan Wakil Presiden lebih lanjut diatur dalam undangundang" sebagai manifestasi mandat UUD 1945 kepada pembentuk undang-undang dapat membuat syarat "threshold" tidak tepat, karena pasal a quo tidak mengatur tentang persyaratan, melainkan masalah cara, karena syarat sudah diatur dalam Pasal 6 UUD 1945, tidak dapat dicampuradukkan. ${ }^{67}$

${ }^{66}$ Lihat Putusan Mahkamah Konstitusi Nomor 5152-59/PUU-VI/2008.

${ }^{67}$ Lihat Putusan Mahkamah Konstitusi Nomor 5152-59/PUU-VI/2008.
Tahun 2013, perihal norma ambang batas ini kembali di uji di Mahkamah Konstitusi, dan Mahkamah melalui putusannya Nomor 14/PUU$\mathrm{XI} / 2013$ tetap konsisten memutuskan bahwa ambang batas atau presidential threshold adalah konstitusional. Mahkamah berpendapat, dengan penyelenggaraan Pemilu Presiden dan Wakil Presiden dan Pemilu Anggota lembaga perwakilan dalam pemilu serentak maka ketentuan pasal persyaratan perolehan suara partai politik sebagai syarat untuk mengajukan pasangan calon presiden dan wakil presiden merupakan kewenangan pembentuk undang-undang dengan tetap mendasarkan pada ketentuan UUD $1945 .{ }^{68}$

Legal policy pembentukan undang-undang haruslah menerapkan tiga prinsip mendasar yaitu moralitas, rasionalitas dan keadilan. Lantas prinsip keadian apa yang digunakan dalam sistem ataupun pengaturan ambang batas sebagai syarat bagi partai politik untuk mengusulkan pasangan calon Presiden dan Wakil Presiden. Sejati sistem ini justru akan mengakibatkan hilangnya cita rasa keadilan dalam penyelenggaraan pemilu.

Pada tahun 2017 pengaturan ambang batas yang tertuang dalam Pasal 222 UU Pemiu kembali di uji lagi di Mahkamah Konstitusi oleh ketua umum Partai Islam Damai Aman (Idaman) dan sekeretaris jendral partai tersebut yang merasa terdiskriminasi atas peraturan ambang batas. Dalam putusannya Nomor 53/PUU-XV/2017 tetap konsisten memutuskan bahwa ambang batas adalah konstitusional.Mahkamah bependapat bahwa dalil diskriminatif tidak tepat digunakan dalam hubungan ini karena tidak setiap perbedaan perlakuan bersifat diskriminatif. ${ }^{69}$ Selain itu Mahkamah Konstitusi juga berpendapat bahwa pengaturanambang batas nanti akan menguatkan sistem presidensial karena presiden dalam menjalankan roda pemerintahan tidak akan mendapatkan kesulitan karena basic dukungan dari mayoritas jumlah di parlemen.

68 Lihat Putusan Mahkamah Konstitusi Nomor 14/PUU-XI/2013.

69 Ant, "Putusan Uji Materi Ambang Batas Pencalonan Presiden MK Nyatakan Konstitusional", dalam Analisa, 12 Januari 2018, hal. 1 dan 8. 
Menarik ketika berbicara prihal penguatan sistem presidensial dihubunhgkan dengan ambang batas pencalonan Presiden dan Wakil Presiden.Ambang batas diperlukan untuk menjaga stabilitas pemerintah dalam membangun hubungan dengan lembaga legislatif. Hakim Konstitusi Saldi Isra dan Suhartoyo dalam perbedaan pendapat di putusan MK Nomor 53/PUU-XV/2017 menyatakan bahwa, pandangan demikian hadir disebabkan praktik sistem presidensial lebih banyak ditandai dengan masalah mendasar, yaitu bagaimana mengelola relasi antara presiden dan pemegang kekuasaan legislatif. Jamak dipahami, karena samasama mendapat mandat dari rakyat, praktik sistem presidensial acapkali terjebak dalam ketegangan hubungan antara eksekutif dan legislatif. Praktik demikian sering terjadi jika kekuatan partai politik mayoritas di lembaga legislatif berbeda dengan partai politik pendukung presiden. Sementara itu, jika partai politk mayoritas di legislatif sama dengan partai politik presiden atau mayoritas partai politik legislatif mendukung presiden, praktik sistem presidensial mudah terperangkap menjadi pemerintahan yang otoriter. Kondisi dilematis ini dikenal sebagai paradox of presidential power ${ }^{70}$

Bahwa bilamana dikaitkan dengan frasa "pemilu anggota DPR sebelumnya" dalam Pasal 222 UU Pemilu, pertanyaan elementer yang perlu dikemukakan: apakah frasa tersebut dapat dibenarkan sebagai sebuah open legal policy? Kebijakan hukum terbuka adalah suatu yang dapat dibenarkan sepanjang tidak melanggar moralitas, rasionalitas dan ketidakadilan yang intotable. Memaknai moralitas dalam perumusan norma hukum dapat dilacak dengan alat ukur yang sangat sederhana, yaitu seberapa besar pembentuk undang-undang memiliki himpitan kepentingan dengan norma atau undang-undang itu sendiri. Bagaimana mungkin menilai kehadiran norma Pasal 222 UU Pemilu jika ia sengaja dirancang untuk menguntungkan kekuatan-kekuatan politik yang menyusun norma itu sendiri, dan di sisi lain merugikan secara nyata kekuatan politik yang tidak ikut dalam merumuskan norma Pasal 222 UU

70 Lihat Putusan Mahkamah Konstitusi Nomor 53/PUU-XV/2017.
Pemilu tersebut. Sementara itu, rasionalitas adalah menggunakan dasar argumentasi untuk menemuka kebenaran. Dalam hal ini, bagaimana mungkin menerima rasionalitas di balik penyusunan norma Pasal 222 UU Pemilu ketika hasil Pemilu DPR 2014 digunakan sebagai dasar pengusulan calon presiden dan wakil presiden pemilu 2019. ${ }^{71}$

Pasal 6A ayat (4) UUD NRI Tahun 1945 telah memberikan solusi apabila nantinya pasangan calon Presiden dan Wakil Presiden banyak jumlahnya, dan akan memecahkan banyak suara sehingga tidak ada pasangan yang memperoleh ketentuan lebih dari 50 persen. Dalam hal ini dua pasangan calon Presiden dan Wakil Presiden yang mendapat suara tertinggi akan dipilih kembali secara langsung oleh rakyat dalam putaran kedua pilpres, sehingga tidak ada partai politik ataupun pasangan calon Presiden dan Wakil Presiden yang dibatasi haknya oleh sistem ambang batas.

Pemberlakuaan ambang batas dalam pencalonan Presiden dan Wakil Presiden sesungguhnya sangat bertentangan dengan semangat pemilu yang demokratis. Selain itu juga sangat jelas menciderai nilai keadilan dan merugikan bagi partai politik peserta pemilu yang tidak diberikan kesempatan mengajukan pasangan calon Presiden dan Wakil Presiden karena tidak cukup memiliki kursi atau suara bahkan, tidak sama sekali memiliki itu semua bagi partai politik peserta pemilu yang baru dalam presentase suara pemilu sebelumnya.

\section{Penutup}

Setelah diuraikan tentang Kedudukan Partai Politik Dalam Mengusulan Pasangan Calon Presiden Dan Wakil Presiden, Pengusulan Pasangan Calon Presiden Dan Wakil Presiden Dengan Sistem Ambang Batas Pencalonan Presiden Dan Wakil Presiden, Hak Konstitusional Partai Politik Dalam Mengusulkan Pasangan Calon Presiden Dan Wakil Presiden Dengan Adanya Ambang Batas Pencalonan Presiden Dan Wakil Presiden, maka dapat disimpulkan bahwa; Pertama, Partai politik menempatkan urgensinya

\footnotetext{
71 Lihat Putusan Mahkamah Konstitusi Nomor 53/PUU-XV/2017
} 
dalam pemilihan umum, dimana pemilihan umum tidak akan pernah terpisah dari partai politik. Para kandidat ataupun kontestan yang nantinya akan menduduki suatu jabatan di negara ini seperti jabatan di kekuasaan eksekutif (Presiden dan Wakil Presiden, Gubernur dan wakilnya, Bupati dan wakilnya, maupun Walikota dan wakilnya) serta jabatan di kekuasaan legisatif (DPR dan DPD). Pemilihan umum maupun pemilihan kepala daerah telah menempatkan posisi partai politik sebagai konstestan ataupun pengusung peserta (calon pejabat publik) dalam ajang pesta demokrasi di negara kita. Legitimasi peraturan perihal tersebut secara yuridis telah diatur di UUD NRI Tahun 1945 maupun Undang-Undang Nomor 2 Tahun 2011 Tentang Partai Politik. Pasal 6A ayat (2) UUD NRI Tahun 1945 menyebutkan "Pasangan calon Presiden dan Wakil Presiden diusulkan oleh partai politik atau gabungan partai politik peserta pemilihan umum sebelum pelaksanaan pemilihan umum". Berdasarkan pasal tersebut, konstitusi Republik Indonesia mengamanatkan bahwa dalam hal pengusulan pasangan calon Presiden dan Wakil Presiden adalah hak konstitusional partai politik. Tidak ada kemungkinan sama sekali bagi pasangan calon Presiden dan Wakil Presiden perseorangan atau independen di luar dari yang diusulkan oleh organisasi politik yang dikenal dengan partai politik; Kedua, Penyelenggaraan pemilihan umum Presiden dan Wakil Presiden di Indonesia pasca perubahan UUD NRI Tahun 1945 mengenal ketetentuan ambang batas pencalonan Presiden dan Wakil Presiden atau yang biasa diistilahkan Presidential Threshold. Ambang batas pencalonan ini digunakan sebagai prasyarat dalam pencalonan Presiden dan Wakil Presiden yang diusungkan oleh partai politik atau gabungan partai politik. Pengaturan ambang batas tersebut diatur dalam Pasal 222 Undang-Undang Pemilu menyebutkan, "Pasangan Calon diusulkan oleh Partai Politik atau Gabungan Partai Politik Peserta Pemilu yang memenuhi persyaratan perolehan kursi paling sedikit 20\% (dua puluh persen) dari jumlah kursi DPR atau memperoleh $25 \%$ (dua puluh lima persen) dari suara sah secara nasional pada pemilu anggota DPR sebelumnya". Jika berdasarkan jumlah kursi berarti hitungannya 20 persen dari 560 kursi DPR atau 112 kursi. Artinya partai politik atau gabungan partai politik yang memiliki 112 kursi di DPR dapat mengajukan pasangan calon Presiden dan Wakil Presiden. Selain berdasarkan jumlah kursi, pengajuan pasangan calon Presiden dan Wakil Presiden dapat dilakukan berdasarkan perolehan suara sah nasional dalam Pemilu Anggota DPR. Partai politik atau gabungan partai politik harus menebus 25 persen suara. Untuk menentukan angka 25 persen perolehan suara sah secara nasional dalam Pemilu Anggota DPR akan diketahui setelah penetapan rekapitulasi penghitungan suara secara nasional. Dengan demikian ada dua cara bagi partai politik peserta pemilu agar dapat mengusulkan pasangan calon Presiden dan Wakil Presiden, baik dengan cara memperoleh suara di DPR atau legislatif sebesar 20 persen atau dengan cara mendapat suara sah nasional sebesar 25 persen. Ketiga, Pasal 6A ayat (2) UUD NRI Tahun 1945 yang menyatakan bahwa, pasangan calon Presiden dan Wakil Presiden diusulkan oleh partai politik atau gabungan partai politik peserta pemilihan umum sebelum pelaksanaan pemilihan umum. Penyelenggaraan pemilihan umum Presiden dan Wakil Presiden di Indonesia pasca perubahan UUD NRI Tahun 1945 mengenal ketetentuan ambang batas pencalonan Presiden dan Wakil Presiden atau Presidential Threshold. Peraturan mengenai ambang batas tersebut jika ditelaah akan merestriksi ataupun membatasi hak-hak konstitusional partai poitik dalam mengusulkan pasangan calon Presiden dan Wakil Presiden. Partai politik yang tak cukup suaranya sesuai ketentuan ambang batas, tidak akan bisa untuk mengusulkan pasangan calon Presiden dan Wakil Presiden. Presidential threshold dinilai akan mencidrai rasa keadilan seperti yang termuat dalam Pasal 28C ayat (2) dan Pasal 28D ayat (1) UUD NRI Tahun 1945. 


\section{DAFTAR PUSTAKA}

Ali Zainuddin. 2009. Metode Penelitiaan Hukum. Jakarta: Sinar Grafika.

Andryan. 2017. Dinamika Ketatanegaraan Rezim Reformasi. Medan: Pustaka Prima.

Ani Sri Rahayu.2014Pendidikan Pancasila \& Kewarganegaraan (PPKn). Jakarta: Bumi Aksara.

Arsyad Sanusi. 2011. Tebaran Pemikiran Konstitusi. Jakarta: Milestone.

Dahlan Thaib, et al. 2015. Teori Hukum Dan Konstitusi. Raja Grafindo Persada: Jakarta.

Dewa Gede Palguna. I. 2013. Pengaduan Konstitusional (Constitutional Complaint). Jakarta: Sinar Grafika.

Hans Kelsen. 2016. Teori Umum Tentang Hukum Dan Negara. Bandung: Nusa Media.

Jimly Asshiddiqie. 2016. Konstitusi Bernegara. Jawa Timur: Setara Press.

\section{Pokok-Pokok Hukum}

Tata Negara Indonesia. Jakarta: Bhuana Ilmu Populer.

John Rawls. 2011. Teori Keadilan. Yogyakarta: Pustaka Pelajar.

Kacung Marijan. 2010. Sisem Politik Indonesia. Jakarta: Kharisma Putra utama.

Miftah Thoha. 2014. Birokrasi Politik \& Pemilihan Umum Di Indonesia. Jakarta: Kencana.

Miriam Budiardjo. 2008. Dasar-Dasar Ilmu Politik. Jakarata: Gramedia Pustaka Utama.

Moh. Mahfud MD. 2014. Politik Hukum Indonesia. Jakarta: Rajawali Pers.

Ni'matul Huda dan Imam Nasef. 2017. Penataan Demokrasi \& Pemilu Di Indonesia Pasca Reformasi. Jakarta: Kencana.

Patrialis Akbar. 2015. Lembaga-Lembaga Negara Menurut UUD NRI Tahun 1945. Jakarta: Sinar Grafika.

Titik Triwulan Tutik. 2010. Konstruksi Hukum Tata Negara Indonesia Pasca Amandmen UUD 1945. Jakarta: Kharisma Puta Utama.

Zudan Arif Fakrulloh. 2014. Hukum Indonesia Dalam Berbagai Perspektif.Jakarta: Rajawali Pers.

\section{Sumber Lain}

Undang-Undang Dasar Negara Republik Indonesia Tahun 1945 .

Undang-Undang Nomor 7 Tahun 2017 Tentang Pemilihan Umum.

Undang-Undang Nomor 24 Tahun 2003 Tentang Mahkamah Konstitusi.

Undang-Undang Nomor 2 Tahun 2011 Tentang Partai Politik.

Putusan Mahkamah Konstitusi Nomor 51-5259/PUU-VI/2008.

Putusan Mahkamah Konstitusi Nomor 14/PUU$\mathrm{XI} / 2013$.

Putusan Mahkamah Konstitusi Nomor 53/PUU$\mathrm{XV} / 2017$

Ahmad Farhan Subhi. "Pengusulan Pasangan Calon Presiden Dan Wakil Presiden Sebagai Peserta Pemilu Menurut Undang-Undang Pilpres". Jurnal Cita Hukum. Vol. 11 No. 2. Pada Desember 2015.

Artis."Eksistensi Partai Politik dan Pemilu Langsung Dalam Konteks Demokrasi Indonesia.Jurnal Sosial Budaya.Vol. 9 No. 1. Pada Januari-Juli 2012.

Didik Sukirno. "Menggagas Sistem Pemilihan Umum Di Indonesia”.Jurnal Konstitusi.Vol. II No. 1. Pada Juni 2009.

I Made Putra Wijaya. "Mengukur Derejat Demokrasi Undang-Undang Nomor 42 Tahun 2008 Tentang Pemilihan Umum Presiden dan Wakil Presiden".Jurnal IUS. Vol. II. No. 6. Pada Desember 2014.

Leo Agustino. "Pemilihan Umum di Indonesia Tahun 2014". Jurnal Prisma. Vol. 33. No. 1. Pada 2014

Lutfil Ansori. "Telaah Terhadap Paresidential Threshold Dalam Pemilu Serentak 2019".Jurnal Yuridis. Vol. 4 No. 1. Pada Juni 2014.

Muhammad Siddiq Armia, Nafrizal, M. Deni Fitriadi, Iqbal Maulana. "Penghapusan Presidential Threshold Sebagai Upaya Pemulihan Hak-Hak Konstitusional", Jurnal ArRaniry Vol. 1 No. 2. Pada Oktober 2016.

Widya Setiabudi Sumadinata, R. "Dinamika Koalisi Partai-Partai Politik di Indonesia Menjelang dan Setelah Pemilihan Presiden 
Tahun 2014". Jurnal Wacana Politik. Vol. 1 No. 2, Pada Oktober 2016.

Ant," Putusan Uji Materi Ambang Batas Pencalonan Presiden MK Nyatakan Konstitusional", Opini, Harian Analisa, Jum'at, 12 Januari 2018.

Anis Azizah, "Sistem Pemilihan Umum", melalui www.kompasiana.com, diakses Kamis, 04 Januari 2018, Pukul 21.50 wib.

Bisma Alief Laksana, "Diusung PBB Jadi Capres, Yusril Segera Gugat Presidential Threshold", melalui www.detiknews.com, diakses Senin, 23 Oktober 2017, Pukul 15.00 wib.

Edy Kurniawan, "Partai politik Dan Pemilu", melalui www.belajarhukumonline.com, diakses Jum'at, 5 Januari 2017, Pukul 15.00 wib.

Kementerian Hukum dan Hak Asasi Manusia Republik Indonesia, "Peran Partai Politik Dalam Penyelenggaraan Pemilu Yang Aspiratif Dan Demokratis".

melaluiditjenpp.kemenkumham.go.id, diakses Senin, 08 Januari 2018, Pukul 21.30 wib.

No Name, "KPU Sahkan Hasil Pemilu, PDIP Nomor Satu", melalui www.bbc.com, diakses Selasa, 16 Januari 2017, Pukul 22.30 wib.

Pono Bum, "Presidential Threshold", melalui $w w w$.academia.edu, diakses Selasa, 16 Januari 2017, Pukul 12.15 wib.

Vhanda, "Ini Syarat dan Tata Cara Pengajuan Capres", melalui www.detiknews.com, dikses Selasa, 16 Januari 2017, Pukul 20.00 wib. 